\title{
Hourat of fluman sciences
}

Volume 15 Issue 4 Year: 2018

\section{The role of global actors on the failed transition to democracy in Egypt ${ }^{1}$}

\author{
Şuayip Turan ${ }^{2}$
}

\begin{abstract}
The paper aims to roles of the global actors on the failed transition to democracy in Egypt. In this study, the negative political influence of powerful states on Egypt evaluated in terms of democracy. The current social inequality in the region continued to increase in the 2000s. Egypt's authoritarian leader were not able to establish the relations between state structures and citizens in the last decade. The global actors had crucial roles on the continuation the authoritarian regime in Egypt. They were easily able to get their demands from Hosni Mubarak. When the time was at the end of 2010, the popular uprising movements affected the Middle East and North Africa (MENA) region deeply. Egypt was one of the most remarkable countries in the region where Hosni Mubarak ousted. The people in Egypt wanted to have a democratic rule in order to have solutions to the social inequality, favoritism, and corruption. Normally, the powerful global actors should have played positive role so as to enable democratic transition. The United States of America and the European Union needed a more proactive policy along with the acceptability of a democratic criteria. Unfortunately, external actors were silent in the following the process in the first place because they were caught unprepared for the Arab Spring and did not expect such a result. Later on, foreign powers supported the counter-revolution in Egypt when they saw that the things did not go as they would have liked. They expressed their support most clearly in the post-coup statements discussing military and financial issues.
\end{abstract}

Keywords: Egypt; democracy; Arab spring; transition; coup'd'etat; counter-revolution; Middle East and North Africa (MENA).

\section{Introduction}

Throughout Egypt's history, there have always been global actors with weak positive political influence under the name of democracy promotion. They served for the authoritarian regime in the shape of economic grants in Egypt rather than promoting the democratization. Eventually, while supporting democratization in the country politically via huge amount of aids and grants, the global actors, the westerners and powerful regional countries abstained from criticizing the repressive policies the regime had over the opponents namely Muslim Brotherhood. Dictators' governance of countries with authoritarian regimes for many years has undoubtedly caused a rise in the longing for the democracy of the people of the region. In addition, institutional transformations in these countries cannot be achieved in the post-Cold War era. The existing social inequality in the region continued to increase after the 2008 crisis. The youth population, which is the most

\footnotetext{
1 This article is formed from the author's Ph.D thesis named "Failed Transition to Democracy in Egypt"

2 Academician Dr., Çankırı Karatekin University, Rectorate, Head of International Affairs, suayip turan@hotmail.com
} 
damaged class from this crisis, has started to uprise in order to get their rights. Authoritarian leaders of the region were not able to set up relations between state structures and their citizens. The reason for this was that the oil-rich countries of the region had state structures that did not need political institutions to provide representative justice. Some scholars like (Fortna and Huang, 2012: 803; Abbasi, 2012: 9) claimed that "oil and democracy do not coexist in any part of the world." In the period of state-building, the purpose of Arabism is to function as glue, tribal system, kinship ties brought by feudalism, favoritism, and corruption which have emerged as the greatest obstacle to the development of democracy in the region. Countries and their leaders who were not very rich in terms of underground resources such as Egypt and Tunisia had provided economic benefits for regime pros with thanks to their sectarian relations. The development brought about by economic modernization led to an increase in corruption, and favoritism to the regime bias, which led to a more rigid authoritarian regime leading to the management style. Strong authoritarian regimes had continued to become stricter to the basic human rights violations. Yet, the political liberalization that should be expected as a result of the changing movements does not seem possible in the near future. The most important proof of the paradigm forgetting political liberalization, before the "Arab Spring", which was generally built on economic liberalization, was the rhetoric of popular movements. The reasons for the uprising in the region were not only the economic difficulties. The new generation of the Arab population is a more politically and pragmatically structured generation that uses technology better and is aware of the living standards of its peers in other geographies of the world. In this context, the European Union needs a more proactive policy along with the acceptability of a more active European Union in the perspective of the people of the region who are going to increase accordingly. Perthes (2011) stated about the reaction of the EU and USA to the 'Arab Spring' as;

The European Union and the United States, taken by surprise by the sudden outbreak of the Arab Spring, have had to accept their lack of influence over these revolutionary upheavals. They may assist or obstruct, but they cannot determine the course of events. This applies even to Libya. Without NATO's intervention, it would certainly have taken much longer to oust the Gadhafi regime. Whether Libya, however, remains divided or spirals into anarchy, whether the outcome will be a new dictatorship, some kind of tribal confederation or the emergence of a democratic system, will be decided by Libyans, not by Europe or NATO. If anything, the limited influence of Europe and the international community on the timing and progress of the uprisings is an advantage. Alongside their peaceful trajectory, the beauty of the Egyptian and Tunisian revolutions was that they were autochthonous; immune to accusations of foreign meddling, but having little influence is not the same as escaping all responsibility (p.73).

Therefore, it is imperative that Western states or institutions, which should not be forgotten, help with the election of the territorial rights, should not escape this responsibility. It is a fact that the western world has not taken as much responsibility for the arrival and settlement of democracy and human rights. Transformation and changes may be risky. In this respect, European Union had been indifferent to taking part in contributing to the transformation of the region, and EU had not taken responsibility for democracy and civil liberties in the MENA. The most important factor that distinguishes the experience of revolution in Egypt from the ones that have existed before is that the external actors are intensely involved in the developments experienced in this process. Although many foreign actors were caught unprepared for the developments in Egypt when they engaged at a very low level in the early period of the revolution which started on the $25^{\text {th }}$ January 2011, regional and global actors in the following period had crucial roles in the country's political developments by rapidly repositioning. The period in which this situation is most explicitly experienced is the period of counter-revolution. Global actors were silent in the following the process in the first place because they were caught unprepared for the Arab Spring and did not expect such a result. Later on, foreign powers supported the counter-revolution in Egypt when they 
Turan, S.. (2018). The role of external factors on the failed transition to democracy in Egypt. Journal of Human Sciences, 15(4), 2357-2375. doi:10.14687/jhs.v15i4.5598

saw that the things did not go as they would have liked. They expressed their support most clearly in the post-coup statements discussing military and financial issues.

The supporters of the counter-revolution, which was organized after the sixth month of the Muhammad Morsi period, soon became an active force. At this point, the internal actors who have lost their power in the revolutionary period have come into commission and have started the process of counter-revolution with the support by the governments of Saudi Arabia and the United Arab Emirates in the region. It should be noted that the importance of the alliances that these internal actors have established along with the external actors in carrying out the counterrevolution. Despite the support of the armed forces, the media and the business world, counterrevolutionary internal actors needed the support of global actors, especially in their economic sense. As a matter of fact, this external support has great importance in ensuring the legitimacy of future administration of power in the process of counter-revolution. Inside the counter-revolutionary front, regional actors, as well as the support of actors at the global level, successfully managed the process. In this respect, although the internal actors were direct actors in the process of counterrevolution in Egypt, they got the support of global actors who have succeeded in realizing them. This external support also initiated the process of internationalization of the Egyptian revolution with the counter-revolutionary process. In this process not only the actors in Egypt but also regional and global countries, international organizations, supranational organizations and transnational organizations were involved in the revolutionary process in a sense as counterrevolutionary support in Egypt. Direct involvement of global actors was often painful in the previous revolutionary process which has been very explicit in the case of Egypt. Egypt is another example of the counter-revolution in that some countries favoring the protection of the status quo supported by the institutions and figures of some countries, create the scene of the revolutionary movement.

In the case of Egypt, the regional countries that most strongly supported the counterrevolution movement were Saudi Arabia, United Arab Emirates and Kuwait. These countries supported Sisi regime both financially and politically, and they demanded that the counterrevolutionary process is carried out successfully. The alliance of the Gulf States with the Egyptian army, which also includes the former regime actors, should be seen as a result of co-operation with the past. As a matter of fact, the coup d'état architect Abdulfettah El-Sisi developed important relations with Saudi Arabia. Likewise, Hazem El-Biblavi, who was the first prime minister after the coup, stayed in Kuwait for 18 years as well as in the Arab Money Fund in the United Arab Emirates for 11 years. Farouk (2014) stated that "as a matter of fact, the first congratulations to Sisi after the military coup on the $3^{\text {rd }}$ July were Riyadh, Abu Dhabi and Kuwait, and these three countries became direct supporters of the coup d'état and thus the counter-revolutionary period" (pp. 9-10). In this part, which is to uncover the role that the global actors had in the course of the counter-revolution, the roles of both global and regional actors in Egyptian politics will be analyzed. Since the involvement of the external actors in the revolutionary process, the revolutionary literature shows them as less experienced than the role played by the internal actors; this part is important in that it constitutes a new example in this field.

The Middle East and the Gulf countries are designed by an absolute global power. The leading countries here have been the United States and the Western Countries that have formed the system of the region within the framework of a capitalist system. After 1970, when the oil began to be used as a weapon, the countries of the region felt the influence of the designing countries more and more. In the Gulf States, we see that the state establishment is shaped by a family/dynasty as that they exist in the management of the families throughout their history. These families have used the people who live under the authoritarian regime in order to guarantee their existence, the achievements of the trade that precedes the geostrategic position. After the discovery of petroleum, they have gone to the benefit of distributing a portion of their gains from the oil rent to make the small profit partner and thus managing them. When this profit was not possible or sufficient to their citizens, the authorized family made an agreement with the powerful states that were active at 
that time in order to protect their sovereignty. This was because military forces were insufficient or they could not trust the existing military forces or the police forces. To get the blessings that the Gulf and Middle East region wanted, the powerful states allowed existing families to enrich their oil wealth with oil after the commerce and before they were able to govern the small states where the Western Democratic meaning was not allowed to be created. Stability and democracy in these regions are particularly necessary as long as it permits uninterrupted flow of oil or natural gas. Indeed, while analyzing the countries affected by the mass uprisings, the dictators or the families of the theocratic rulers influenced by the Arab Spring were in relatively good relations with the West till that time. Of course, on the basis of this relationship lied bilateral earnings. Therefore, while evaluating the Arab Spring movements, it is important to take about the following points by granting the complaints of the regimes. It may be a reductionist approach to see these movements as just a struggle for freedom of the oppressed or the people's communities.

In these social movements, which are described as Arab Spring and military coup in Egypt, some analysts think that the United States is behind the events and that it is the restructuring of geography as part of the Greater Middle East Project. In this context, a point of view that global forces are the ones that mobilize the internal dynamics in Arab geography gains strength. Mahalli (2011) stated that even the American newspapers say 'the Central Intelligence Agency (CIA) is helping the Syrian opposition', but some still talk about the struggle for democracy in this country and they do not see the big game being played there. They either do not want to see it or they are not allowed to see it. Therefore, there was the existence of a hegemonic point of view that made things in a plan and program. Western countries leading the United States and their democratic or non-democratic supporters are trying to put in place or deliberatively say that everything is complicated in the name of democracy. According to the West, however, the Islamist parties, which came to power with the Arab Spring, have no experience of democracy and will not be able to make political, economic and social choices without different contradictions. In addition, the social and cultural character of these countries and their political and economic characteristics are not similar to Israel, the USA or European countries. If this is not the case, there can be a suitable democracy for them. The Arab Spring could be another name for the completely justified claims of the Arab people who have been forced to live under the oppression of the dictators for decades with their dignified struggles. However, in countries that live "in the spring" there has been no change in the living conditions of the people and this will never happen because the concept of democracy is a way of life that has political, economic, social, cultural and psychological dimensions. Using free will voting is only one dimension, but it is not a very important dimension. The basic concept that should not be ignored in Arab democracies is honor. The honor will not be provided by tanks, planes, and dollars from the US or NATO. Qatar and Saudi riyals will never get the honor of Egyptian people. If the illiterate, poor, unemployed and hungry Egyptian are frightened before going to the ballot, and they have been convinced that all their problems would be solved, then there was a problem in this democracy.

The United States, which has been described as the hegemonic power of the world, has been following important events that have emerged around the world, and they are striving to be involved in the process. Once the process is complete, they are always on the move in the direction of their own interests. When we consider the Egyptian example, the US wants to secure its own interests first and then Israel's security and future. The US wanted to shape the post-Mubarak era in Egypt within its own interests. In the first place, the Muslim Brotherhood's coming to power and representing the majority was not directly beneficial for their self-esteem. As a matter of fact, to intervene in this political affair, the US first provoked the other part of the people by using internal dynamics. The army has also achieved its goal by incorporating it into its business. On the way to the target, the United States was in contact with key actors in the country. Ultimately, the minority is superior to the majority. 
Turan, S.. (2018). The role of external factors on the failed transition to democracy in Egypt. Journal of Human Sciences, 15(4), 2357-2375. doi:10.14687/jhs.v15i4.5598

\section{The Role of the United States of America}

The United States of America, which was caught unprepared for the revolutionary process in Egypt and could not develop a coherent policy for this country for two years, also showed an inconsistent attitude during the July 2013 coup. The USA, after the declaration of the will of the Egyptian army to make a military coup, invited MB to reconcile with the opposition by meeting with Hayrat Shatır, one of the well-known leaders of the MB, yet with the realization of the coup d'état, the US directly took the side of the new administration which disappointed the supporters of democracy in Egypt. The US administration, which did not give a sincere support to the democratization of Egypt in the post-Mubarak period, failed to react to the demobilization of Morsi, who came to power with democratic elections, in his military coup. In this period, some Egyptian civil societies and figures supported by the USA participated in the anti-Morsi field and contributed to the removal of the first president who came to the country with democratic elections in the country with the military coup. To understand America's reactions, we first need to look at its interests. Yazıc1 (2014) emphasized that "for ages, the West has never worried about the democratization of the Arab world, and nothing matters for the West except the regional stability and their economic interests" (p.104). The EU and USA formed several military bases in Egypt and made military aid agreements. While America's belief in the developmental dominance of the world continues, a result of the internal dynamics of the Egyptian uprisings is considered the first sparks of the Arab Spring. Oğuzlu (2011) informed that prior to the Arab Spring, America's interests in the region were establishing close ties with Israel, facilitating the flow of oil to the West and making it difficult for other global powers to access the region. Before the Arab Spring, everyone in the region was aware that some states were seen as one of the most important threats by the USA. The existence of some nuclear weapons claimed by the US made it possible for all American governments to be regarded as the most important regional threat. With the demands of radical religious governance, the countries questioned Israel's existence and legitimacy in the most brutal manner. Prashad (2012) informed that the events at Tahrir Square echoed in Washington. The prospect of a growing wave of protests spreading throughout the region has made America uneasy. Because of the uncontrolled events, American politicians were questioning the following: was the US power in the region shaking? How would Israel respond to the fall of the Mubarak regime? With confidence and enthusiasm brought about by the fall of Mubarak and Ben Ali, what would bring to the Emirates in Yemen and Saudi Arabia and the Gulf of Basra? For this reason, internal turmoil in the revolutionary countries like Tunisia and Egypt could serve America's interests. Therefore, the attitude of America had been to strive for ways of falling how to favor with them. Bingöl (2007) asserted that "in terms of the interests of America, rather than bringing the democratic and libertarian governments to work, it will be the most rational choice to contribute to its regional policies and to keep the most faithful and closest political staff on the job. In this context, it is often a favorable choice for the interests of the United States to support a certain degree of authoritarian rule, free from the public and therefore democratic norms" (p.16). The Middle East accounts for 41.5 percent of world natural gas reserves, $55.5 \%$ of its reserves. A more striking example is that Qatar's natural gas reserves alone can heat up all the houses in the US for a hundred years. There are also advantages when the Middle East and the Gulf are controlled by international powers. Yazıc1 (2014) cited from a Noam Chomsky's report that "the US never permits the processes of democratization to develop fully in the Arab world, and they will allow only managed democracies in the region. The US supported the regimes in the Arab world for the economic interests, and then withdrew the support for the sake of democracy" (p.105). The US wanted to control the MENA region as a tool of the world superpower. The US, which sees Europe as an important competitor, is more or less comparable to the US in terms of economy and population. The way to keep Europe under control is to make it dependent on oil by controlling the oil on its own. 
Turan, Ş. (2018). The role of external factors on the failed transition to democracy in Egypt. Journal of Human Sciences, 15(4), 2357-2375. doi:10.14687/jhs.v15i4.5598

Egypt always had an important position in the Arab world. So as to explain the policy of the US towards Egypt, it is necessary to examine Egypt's relations with Israel, the West and the Islamic world. Following the popular uprising that took place in January 2011, after ousting Hosni Mubarak, the ruling soldiers took a decision to open the Gaza border with Palestine in the spring of 2011. This was done in order to secure their own legitimacy and to control the potential social opposition and anger. Then the Muslim Brotherhood, who took over the power, kept the human corridor open to Gaza and keep the Hamas and Fatah support consensus negotiations. The Muslim Brotherhood candidate in a general sense, the Morsi administration, favored a relationship based on rational and common interests that would be unexpected in its relations with the West. Morsi's visit to the United States for the UN General Assembly, his negotiations with EU officials in Brussels, and his visit to Italy and Germany were the infrastructure preparations for rational and joint constructive relations. The Israeli attack on Palestine in 2012 is important for the Morsi administration to reveal its side. Morsi played an active role in the movement that led to a visit to Gaza. The new power with Islamic identity was already a usual doubt for the US and Israel. Therefore, one of the first actions of the military regime, who replaced the Muslim Brotherhood by a military coup d'état in 2013, was to close the Gaza border gate.

The attitude of Morsi from an Islamic tradition, the attitude of him after Israel attack on Palestine, and the attitude of the 10 million Christian minority constituting the Egyptian population were in favor of the military regime against the Morsi administration which were decisive in US policies regarding the military coup against Morsi. According to US thinking, millions of Egyptian people worried about the country and wanted the army to intervene on behalf of the government in order to stop the chaos and violence. The United States is undertaking tremendous tasks related to the order of the world. During the Cold War, the United States has used discourses such as civil liberties, democracy and the right of nations to self-determinate to the Union of Soviet Socialist Republics (USSR) as a foreign policy tool. With the collapse of the USSR, the US has abandoned such discourses as democracy, human rights, and the right of the nations to self-determination in a unipolar world while it has focused on 'order' for the continuation of the hegemony. It is possible to say that in this framework, the policy of the USA against the military coup is in the direction of its benefits. America has prevented the Islamic-dominated government from long-term use by taking advantage of Egypt's internal balances for its own interests in the US. Egypt is an important strategic point between Africa and Europe and it is more than useful and practical for the policies of US in the Middle East.

Ever since the first traces of the Arab Spring began to emerge, arguments have been raised that the severe social movements in the region were prepared and directed by the United States. Since the beginning of the Arab Spring, many analysts who were interested in and working on the process had found that the United States has restructured this geography under the Greater Middle East Project (GMEP). The initiatives of the USA in the past in this geography mean that the force of the dominant powers in the world in every period of history, in searching of the new sources, particularly in the geography of the Middle East, means that the potential domino effect in this region was very low by happening spontaneously. There must be a strong power to make the people mobile in order to change the old autocratic regime. Especially, the biggest demand of the global economy, energy like oil and natural gas was the most common in the region; therefore, it reduced the likelihood that large states would give the Middle Eastern People up to the future of the region on themselves. Besides the energy resources, the Middle East has been the center of world trade for centuries. Due to its geopolitical position, this region connects the East and West along with the North and South. However, in the case of both peace and war, this geography is a great market for capitalist forces. In the time of peace, the population living in the region constitutes a large market for the global companies. In addition, the Middle East is the largest market for weapons trade, as it is the place where wars have been prominent in the history. If ideological, ethnic, political and religious reasons also add to these factors, it would be more optimistic to imagine that the imperialist powers would leave the region to their fate. Therefore, the 
Turan, S. (2018). The role of external factors on the failed transition to democracy in Egypt. Journal of Human Sciences, 15(4), 2357-2375. doi:10.14687/jhs.v15i4.5598

recent history of the Middle East clearly demonstrates that there are constant conflicts of interest over this region. The intervention of the USA in Iraq and Afghanistan along with the intervention of the NATO army in Libya and Syria were the proofs of this idea. Undoubtedly, the Western world and especially the United States, the most powerful military-political-industrial complex of the global world, closely followed the improvements in the Middle East. They wanted to intervene in the progressive stages, even if not at the beginning of events. In Egypt, for example, in this sense, the United States had attempted to shape the post-Hosni Mubarak rule in the direction of its own interests and had attempted to establish close ties with key actors for this purpose. America had been quite successful. The Gaddafi administration, which had been in ruling for many years in Libya, had been a threat to the whole world and humanity in the Arab Spring process and military operations had been organized there with the demand of the United States. America chased similar policies on Syria. Without a doubt, the United States was involved in the process in its center. All these reasons leave the impression that the events of Tunisia in the Middle East are spread by domino effect and that millions of people were influenced by the leading of great powers.

The statement of President Obama's post-coup demonstration shows that Washington had an ambiguous policy on Egypt, and yet the USA can be easily adapted to turn against Morsi. Obama has not described the Chief of General Staff Abdel Fattah El-Sisi's Egyptian seizure as a military coup. In addition, he also expressed that Egypt wants rapid democratic governance. Having said that the US would not be able to support the one-party or one-man government, Obama said that Washington would reassess Cairo's aid in the wake of the US's failure to help the countries governed by the military coup and that Egypt must now meet democratic institutions. In the following days of the coup, contacts and high-level statements emerged that the United States was not disturbed by the removal of the Muslim Brotherhood and approved the administration of the country by the military regime under Al Sisi leadership. US Deputy Secretary of State William Burns, who made his first official visit to Egypt after the coup, did not give any reference to the military coup in his statement after he visited the General Abdulfettah Al-Sisi and other transition process leaders. He stated that "the truth is that only Egyptians themselves can make the hard choices required to build an inclusive, tolerant, democratic future," Burns said. "I also know that they will find a determined partner in the United States" (www.dw.com). He also emphasized in his $15^{\text {th }}$ July 2013 visit that "he did not come with American solutions, nor did he come to lecture anyone. America would not try to impose their model on Egypt." This visit, which was made just right after military coup d'état and their statements such as "America were ensured that Egypt would advance towards democracy with this new administration", also gave the signs that America would act with the Egyptian army in the transition period together. Therefore, Burns did not require meeting any members of the $\mathrm{MB}$, who were eager for Morsi's reinstatement. Quite interestingly, he did also not meet with the representatives of "Tamarod movement," the anti-Morsi movement that led to his fall. At that time MB representatives accused the USA of backing or even instigating the coup. The Muslim Brotherhood spokesman Farid Ismail (2013) stated that "the Americans carried out the military coup - they didn't just recognize the new leaders, they carried out the coup. We know, and we have specific information about the communications that preceded the coup, which proves that the US planned it and General Abdel Fattah Al-Sissi executed it" (www.dw.com). Fisk (2013) stated about the issue and America's stance as;

For the first time in the history of the world, a coup is not a coup. The army takes over, depose and imprison the democratically elected president, suspend the constitution, arrest the usual suspects, close down television stations and mass their armor in the streets of the capital. But the word 'coup' does not - and cannot - cross the lips of the Blessed Barack Obama. Nor does the hopeless UN secretary general Ban Ki-moon dares to utter such an offensive word. It's not as if Obama doesn't know what's going on (independent.co.uk).

This also shows that America did not do anything for democracy in Egypt; on the other hand, it supported the coup surreptitiously. In fact, "what democracy aid has done is to represent the superiority of the US model of liberal democracy in maintaining the national interests of the US 
Turan, Ş. (2018). The role of external factors on the failed transition to democracy in Egypt. Journal of Human Sciences, 15(4), 2357-2375. doi:10.14687/jhs.v15i4.5598

at the expense of subject colonial people" (Snider and Faris 2011). The USA gave a high amount of aid, yet this was not spent on the democratic tools or human right organizations. On the other hand, these aids went through for the military which was the main supplier of the regime and the main set against democracy in Egypt. Hamid (2011) confirmed about this aid and its yield as;

Egypt provides unconditional and complete support for US objectives and operations (including anti-terrorism), and provides a big market for US products, while providing legitimacy for Israeli actions (particularly in Gaza, historically considered to fall under the auspices of Egypt in international Arabism), securing access to the Suez Canal and giving use of its airspace for US military operations (p.27).

Also it promoted the military by their statements and also financial support. Therefore, the US administration, which had performed poorly in order to pursue a democratic attitude immediately after the military coup d'état, lost the credibility of democracy in Cairo along with the Egyptian public confidence. Yazıc1 (2014) stated about the attitude of the USA from the news of Washington times and BBC news as;

John Kerry speculated that Egypt's military was restoring democracy and was asked to intervene by millions of people who were afraid of chaos and violence. He said on GEO TV: "The military was asked to intervene by millions and millions of people, all of whom were afraid of a descendant into chaos, into violence. And the military did not take over, to the best of our judgment so — so far." 388 As obvious, the US government rejected to describe removal of Morsi as a coup not to cut off its annual aid to Egypt. Kerry reminded that the military did not take over so far and to run the country, there is a civilian government (p. 129).

Nevertheless, the general policy of the US to post-revolutionary Egypt, whoever comes to power, was the policy of protecting America's interests by developing relations with the administration which has continued more openly during the Sisi's period. The Obama administration has given military and political support to the Sisi and junta regime to guarantee the US interests in the region. The US has been supporting the Egyptian army and the former regime in the aftermath of the coup d'état. Despite the intense pressure campaign against the Muslim Brotherhood movement that damning the violence and the abuses of human rights in the country, the unresponsive attitude of the USA to the Sisi administration, is a proof that Washington does not care about a real sense of democracy in the country. The US aid policy to Egypt has also been achieved by ignoring democratic principles in the interests of Washington. The United States has not announced military intervention as a coup d'état so that 1.5 billion dollars of aid given to Egypt every year cannot be cut off. Yet, after international reactions and increased human rights abuses in Egypt, the USA has frozen $\$ 260$ million in aid to Egypt at that time. In contrast, the US State Department spokesman Jan Psaki indicated that military aid to serve the interests of the USA and Israel would continue and these military aid benefits were vital to the Egyptian terrorist fight and border security issues. As a matter of the fact that US government expressed that apache helicopters which were being delayed to deliver till 2014 would be sent to Cairo as soon as possible. In this way, while the United States continued military aid to Egypt from one side, the US aimed to ensure that the Sisi administration acted in line with US interests.

The oppression politics and human rights violations carried out by the Sisi administration against both the Muslim Brotherhood movement and other revolutionary movements during the counter-revolutionary period in Egypt have not been met with a serious reaction by Washington for a long time. Even so, even if hundreds of MB members were condemned to death in Egypt, the US could not prevent Egypt from transmitting arms aid. Murphy (2014) emphasized that America has been underestimated by the death penalty given as a result of purely political trials. Despite the human rights violations in the country, the decision to maintain military aid to Cairo is an indication that the US preferred democracy to the status quo in Egypt. America continued this policy until Sisi was elected President of the Republic. In the following years, America has supported Sisi more and has contributed to strengthening his international legitimacy. Because of the human rights abuses in 
Turan, S. (2018). The role of external factors on the failed transition to democracy in Egypt. Journal of Human Sciences, 15(4), 2357-2375. doi:10.14687/jhs.v15i4.5598

Egypt and ongoing pressure, a group of intellectuals was asking Obama to cut off military support for Egypt. The Obama administration, which did not listen to the calls, continued to support the coup in Egypt. Abdulfettah El-Sisi, who came to the United States for the United Nations General Assembly, also met with Barack Obama as part of his contacts. Obama met with Sisi despite the call of the human rights institutions to the opposite side. Obama emphasized that Egypt and the US have common concerns, and that the strategic cooperation between the two countries was inevitable. This approach of the Obama administration has not only brought legitimacy to the Sisi regime but has also paved the way for the pressure on opponents of the coup to continue increasingly in Egypt. The United States continued its economic, political and military aid to Egypt after the coup too. US Secretary of State John Kerry underlined that America attaches great importance to Egypt's security and stated that America was ready to make political and economic aid to Cairo for democratization. Secretary of State John Kerry (2015) stated officially in U.S.Egypt Strategic Dialogue forum in Cairo that

... and finally, the last thing, let me just reiterate the United States and Egypt are both at our best when we are working to improve institutions of governance, to support political reform, because good governance is the single most important platform for any country's success in the 21 st century. It's more vital than oil or precious minerals or a deep-water port. And, believe me, we are confronting our own challenges in the United States. We are not suggesting we have all the answers. But we are engaged in a pretty open process of working at our own process to develop ongoing reform. Egypt has a very long, very proud history of independence and leadership. Egypt has really always been the hub of the Arab world and of this region. And we have no doubt that, with the right economic choices and the right choices about governance, Egypt is going to continue to play this vital role. That's why the United States is so deeply committed to this relationship. We are confident that Egypt has really good reason to ensure that the fundamental rights of its citizens are protected, that vital principles such as due process and freedom of press and association are cherished, and that women are empowered, and that every Egyptian has the right to participate peacefully within a truly democratic political process. No great country - and Egypt is without question a great country - should settle for any less... (eg.usembassy.gov).

The USA policy has shown that since the Egyptian military coup, the Washington administration wants an ally to emerge in Egypt that will serve its long-term interests rather than democratize it. Obama administration was aware of the necessity of a strong regime in Egypt for establishing a regime preceded by the regional interests of Israel and the USA which had not seen any disadvantage in supporting the $\mathrm{Al}$ Sisi regime and the counter-revolutionary process in Egypt.

\section{The Role of the European Union}

The European Union is a regional integration process that is constantly evolving with the tendency towards everyday expansion and deepening from the past. The EU has tried to carry out the enlargement with some political, economic and institutional treaties, but decided to carry out a neighboring policy with the neighboring countries at the end of the enlargement process so as to maintain the principle of manageability within the boundaries of the existing borders. The EU has preferred to behave differently to the countries where it attaches more importance to the geographical area, especially in the Middle East. The EU has come to regard the oppressive attitudes of authoritarian regimes in the countries in the light of their political interests. Brussels A 70/13 Press (2013) highlighted the fluency of the democratic situation and underlined "while overall significant progress has been made in promoting democratic reforms (e.g. holding of elections in line with democratic standards, strengthening of the role of civil society, increased freedom of expression and assembly) many obstacles still need to be overcome in order for these transitions to be successfully consolidated" (p.1). Egypt, for example, where the regime was highly oppressive, had also become the most beneficiary of EU funds. There were countries such as Jordan and Morocco, which were geographically important for the EU, although the EU had done 
Turan, S.. (2018). The role of external factors on the failed transition to democracy in Egypt. Journal of Human Sciences, 15(4), 2357-2375. doi:10.14687/ihs.v15i4.5598

little to reform. In short, the EU is in the Middle East politics; democracy, good governance, human rights, the rule of law, etc. aimed at disseminating and developing the concepts, but the result showed the limit of the EU in the subject area.

The regional cooperation that the EU wanted to realize towards the Middle East has faced some difficulties. At the head of these difficulties were authoritarian regimes in the region. The concept of democratization that the EU wanted to promote was inherently dangerous for authoritarian regimes. The mentioned regimes had sometimes resisted changes in the point where they were beginning to clash with their interests, even if they had supported regional cooperation. The conflicts in the Middle East, a challenging geography, had caused the EU trouble in its politics in the region. In addition to the Arab Spring process, internal disturbances and conflicts, stability in the region had suffered serious damage and cooperation had remained quite backward. Of course, as well as adding to the fact that the EU always puts itself at the center as well as positions other collaborators according to EU benefits, bilateral relations had been adversely affected. In addition to all these, the EU was fighting the dilemma of democratization and stabilization in the region. This dilemma was related to the different foreign policy initiatives of member countries, their different interests and their security preferences.

The EU in principle has adopted cooperation and stability as a common foreign policy objective, thus choosing a democracy-based security model. The regional security, free trade and the development of civil society, the EU had assumed that EU could achieve its goal for the Middle East. The failure of the Euro-Mediterranean Partnership policy, the Arab Spring, which started at the end of 2010, as well as the repressive regimes in the Middle East, have prevented it. The EU, which has pursued various policies for the democratization of the Middle East, wanted to guarantee its security on this issue, but in any case, did not support the idea of bringing new ones instead of existing regimes like the US. Since the beginning of its interest in geography, the EU has preferred not to communicate with religion-based movements, preferring to maintain distance with local dynamics. Yet, after 2010, the political power of the political Islamic movements in the MENA increased and their voices started to rise. In the Arab Spring period, the EU's lack of communication was felt deeply and the EU wanted to make up its mistake by recognizing the Muslim Brotherhood Movement in Egypt. This situation has clearly shown that the EU is actively promoting its own security, not spreading the democratization movement in the region. The lack of democracy in that region and Arab countries has created a great security threat for the countries in the West. The political pressure created by the authoritarianism of the regime in Egypt had caused the radicalization of various groups away from the peaceful paths in order to be able to have a say in politics. Therefore, these events threatened the security of the West as a result of regional instability. Emphasizing the need for the development of civil liberties and democracy in the region, the EU has stated that political reforms should be enhanced. However, differences have arisen between what was said and what was done while the changes that the EU has made with the Neighborhood Policy have not been realized. Brussels A 70/13 Press (2013) took the attention on that "EU support to stimulate sustainable economic growth is therefore crucial to the promotion of democratic institutions, provided that the countries of the region contribute to the promotion of a friendly environment for investments, jobs and growth. It should be underlined that economics has a deep connection with politics. An economic collapse would imply a political failure of the transition" (p.2). Economic assistance to support the political reforms in the region has not reached adequate levels and most of the assistance has been transferred to issues such as terrorism, immigration and border control rather than projects to support democracy. That's to say, the EU did not regard the concept of democracy as a self-imposed value but instrumentalized it as a concept that could prevent terrorism, especially targeting the Western countries. The authoritarian regimes have been the most beneficial to this situation, and with the support of the West, they have created a fear that radical Islamic groups would be able to seize power over the people. However, the authoritarian regime's policy carried out by the Western countries had not brought security to the countries of the region. On the other hand, the inadequate political reforms that have been 
Turan, S.. (2018). The role of external factors on the failed transition to democracy in Egypt. Journal of Human Sciences, 15(4), 2357-2375. doi:10.14687/jhs.v15i4.5598

carried out by the authoritarian regimes had worsened the situation in the region. The EU's endorsement of the authoritarian regimes in the political arena to block radical Islamic groups had brought more confusion than stability. For instance, the political rights in Egypt had been reduced and the field of action of civil society organizations had been narrowed. The authoritarian regime became even stronger in countries where repressive regimes were effective.

The EU used some tools to better manage the process in Egypt. These tools to support the construction process included: persuasive international diplomacy, humanitarian aid, various sanctions, embargo, many visits made by the EU representatives to the region (Commission Members, High Representative of the Foreign and Security Policy/Vice-President of the European Commission and members of the European Parliament). When the developments began, perhaps it was unlikely that the events would spread so quickly, that most authoritarian regimes in the region would end, and that the region might have varied in many ways. Arab Spring was initially called with relatively more positive approach at the beginning. Yet, when the time passed, Arab awakening, Arab uprising, Arab revolution, and Arab transformation was called in a different way. However, it is referred and called, one thing is certain that the process is still uncertain and unpredictable as to where it will go. The European Union has given importance to developing its relations particularly in the economic, political and in terms of security with the states, which have the Mediterranean coast. In this context, the EU has placed great emphasis on developing relations with Egypt, one of the most important states of the Mediterranean and the Middle East. The relationship between Egypt and the European states has a long history. The economic and political relationships between the EU and Egypt began to develop, especially in the period of Hosni Mubarak. One of the main reasons for this is that Mubarak was following a foreign policy consistent with the interests of Western states and the EU attached importance to cooperation with Egypt in economic, political and security matters. Mubarak's emphasis on cooperation with Western states had allowed him to be supported during his thirty-year governing power without questioning his government, even though it had not come with democratic elections. The European Union is shaping the democratization of the Middle East region. Archick, Belkin, Blanchard, Ek and Mix (2011) emphasized that first of all, a significant number of African Muslims live within the borders of the European Union. It is estimated that this number is 15 to 20 million. Thus there is a "Muslim ghetto" that can affect political life in European countries and each year there is official and informal migration from the Middle East to Europe. In this case, the number of the Muslim population is increasing rapidly. Secondly, the European Union imports nearly half of its energy sources from the Middle East. The instability in the region or, in other words, the threat of the security of the energy supply is threatening the 'life vein' for Europe. Third, the EU is a major commercial partner of the Middle East countries. The process of conversion, called the Arab Spring, has served as a litmus paper for the differences between the union countries. After this event, the domino effect of the countries of the region is the change of the administrations one after another. It is clear that the basic policies of the locomotive countries of the EU differ, and that the common security and foreign policy, that had become more institutionalized after the Lisbon process, had not worked. Britain, France and Germany have pursued a differentiated foreign policy due to their historical, geographical and varied interests on the MENA region countries, revealing that the unity is not real. How the EU reacts to the changes in the Arab world is presented in the framework of the neighborhood policy, which is dated the $8^{\text {th }}$ March 2011. "Partnership for Democracy and Shared Prosperity with the Southern Mediterranean." This report (2011) stated that "the EU wants to support them in building real democracies and peaceful and prosperous societies. Each country and people will of course choose their own path and make their own choices. It is rightly for them to decide and not for us to seek to impose solutions" (p.14). So as to define the regional policy of the Union, it is stated that the people living in common communities have a historical process which will give result not only for the regional states but also for the whole world as well as the EU. In terms of the people of the region, civil liberties, pluralism, the rule of law and the prospect of social justice flourish, whereas the transition periods of 
Turan, Ş. (2018). The role of external factors on the failed transition to democracy in Egypt. Journal of Human Sciences, 15(4), 2357-2375. doi:10.14687/jhs.v15i4.5598

democracy have never been easy, and the transition process has always been faced with risks and uncertainties. For this reason, it is emphasized that the EU should not be passive, but should be supportive within the framework of the three elements determined by the transition states. European Commission (2011) declared these as;

Democratic transformation and institutional structuring, liberties, constitutional reforms, judicial reform and fight against corruption,

Strong partnerships with the people, support for civil society, increased communication from the people,

Sustainable and inclusive growth and economic development, especially small and mediumsized enterprises (SMEs), health improvement, education systems and the development of poor regions (ec. europa.eu).

The relations between Egypt and the EU are realized within the framework of the European Commission declared document mentioned above. However, we can see that the values written in these documents do not take place in practical relations, and values do not reflect in the actions. In short, there are serious differences between words and actions. The last example of this can be seen just after the coup d'état in Egypt. As a matter of fact, the European Union, which supports the institutionalization and consolidation of democracy and democratic reforms in Egypt, had shown its failure to the illegitimate overthrow of the first elected first president of Egypt. This event led to the questioning of the normative power of the EU. It is also seen in the last case that the European Union that when it is in between values and benefits, European Union has always been in the benefit side; therefore, the values remain in the back seat. Ceyhun (2013) summarized the process of European Union towards Egypt; it was the fact that the emergence in Egypt showed that the Copenhagen Criteria of the EU did not apply to Muslims. Muslims have democratically applied their right of self-determination; this revealed the real faces of some in EU countries because they were at odds with the Copenhagen Criteria in this sample. In particular, it would have been the most sacred of the EU principles to respect the right of the Muslims who claim their own destinies by saying 'more democracy'. The EU, which supported the downfall of the democratically elected president with the military coup in Egypt, understood democracy, however they just chose to serve their own benefits. The Arab Spring has created some serious advantages and opportunities in order for the EU to be able to put forward a common foreign policy while bringing with it a lot of complications. The Arab Spring process seems to be an opportunity to create a new foreign policy on behalf of the member states or to revise the existing one to create a process of repairing its weak sides, but as a result it has not caused a comprehensive political change that could bring the EU's relations with the Middle East geography to a new level. It has not allowed the EU to change its common foreign policy image, which was exhibited before the Arab Spring, to be renewed. The Arab Spring has led to an increase in mutual competition and conflict of ideas between the member states of the EU with the ongoing process of conflict, and the impact of the EU on the process has been further diminished by the fact that the members have their national foreign policies in front of the EU. With the Arab Spring, it is now clear that nothing will be as old as MENA. From now on, the countries in the region will determine their own future, while international actors will have to adapt to the situation in question. Unfortunately, the power struggle that followed the Arab Spring is a battle for global and regional actors to widen their influence in order to dominate the region, leading them to a position than before the revolutions of the region began. In terms of the EU, the situation seems even worse. Whether or not the EU, which is trying to make every opportunity feel like it wants to be a global actor in important regions like MENA, has a real sense of this, the Arab Spring had emerged. The Union, which has been struggling to become a global power, has not succeeded in implementing a common policy in Egypt for the democracy. In this policy difference, conflicts of interest between members and conflicts of ideas are taking great importance. Dersan (2006) stated that "the United States and Europe share key interests with regard to the Middle East. The first and most important common concern related to the Middle East is strategic interests. Both parties express their desire 
Turan, S.. (2018). The role of external factors on the failed transition to democracy in Egypt. Journal of Human Sciences, 15(4), 2357-2375. doi:10.14687/ihs.v15i4.5598

for a stable Middle East since instability and domestic conflicts in the Middle East interrupt commerce, create refugees and generate domestic pressures" (p.100). In other words, the European Union's policy toward the Middle East has been shaped around security, political and economic interests in general terms. Security interests are possible risks from regional conflicts, terrorism, the spread of weapons of mass destruction, and illegal immigration from geographical proximity to Europe. Political interests, on the other hand, are generally peace and stability in conflicts in ArabIsraeli and other regions. Finally, economic interests, a more important issue, include secure access to energy resources along with increased exports of the EU to regional markets. The EU has supported the developments that have taken place in countries in the region since the beginning of the Arab Spring for them to become democratic. The Foreign Ministers of the term stressed civil liberties in the uprising process and explained that they expect the changing governments to respect every aspect of the different social groups in these countries. At the G8 Summit in France in 2011, tips for the EU's new policy on the Middle East and North Africa were announced by German Chancellor Angela Merkel. It has been recommended that new democracies established in consideration of the developments that are realized in the Arab world should be restored to a stable structure so as to resolve the present economic instabilities as soon as possible. It was also emphasized that new governments and reforms should not be in danger. Merkel said that helping the Arab Spring process alone would not provide a solution, and that in the past it had fallen into this fault, and that other basic points were also overlooked because of this mistake. She also stated that Arab countries should take steps to take responsibility for economic and social improvement in the Arab world without ignoring human rights. Merkel emphasized that the EU should play a leading role among other western states in helping to promote economic cooperation and employment policy among Arab countries. Merkel clarified the outline of the foreign policy perspective of the EU towards the MENA region. It was seen that in the process called the Arab Spring, the commercial relations of the European Union with the countries in this region gained concrete momentum.

Less democratic countries have tried to move to a more democratic system with various rebellions and protests with the Arab Spring. However, it has been a difficult process and experience for the MENA countries, which have been governed by colonial and authoritarian regimes until now. The historical heritage of the country, which has an administrative democracy that revolves around an anti-democratic manner like Egypt, has also affected the mentioned democratization process in a negative way. Revolutions in the Arab Spring have initiated a major process of change in the MENA region. Considering the human and natural resources in the region, historical reflexes and the political demands of the people, it is clear that the Arab Spring case is going to cause serious changes and transformations over time. For this reason, it may be wrong for us to make comments about the future of the region with the events that take place only by considering today's hot issues. Moreover, it is not right to evaluate that the developments experienced in the MENA region in the process of transition to democracy as successful or unsuccessful. As a result, people living in the MENA have suffered various experiences which has worn people out over time because of the unrest and demanded democracy. On the other hand, we can understand that no transformation on earth is easy, as the French revolution has begun to show its consequences after almost 200 years.

One of the most challenging exams of the EU foreign policy, at the beginning of 2011, the European Union had five main political aims. These aims were; economic cooperation, immigration and refugee policy, fight against international terrorism, living in peace with its neighbors and human rights, the rule of law, democratization, and modernization. The EU has adopted an approach that promotes economic welfare in providing a democratic transformation in Egypt. The EU has supported the rule of law and increased employment in the transitional cooperation process for Egypt. The EU took a concrete step on the role to play in Egypt's democratic transformation in 2011 with various agreements. The EU stressed the Egyptian people's desire to achieve a promising economic structure, stating that a democratic and human rights-based 
Turan, S.. (2018). The role of external factors on the failed transition to democracy in Egypt. Journal of Human Sciences, 15(4), 2357-2375. doi:10.14687/jhs.v15i4.5598

government should be established and that the demands raised by the people should be taken into account. In February 2011, the first reaction from European Union to Mubarak's resignation came from Merkel. Merkel explained that the resignation of Mubarak was a service and historical change to the people of Egypt as they shared in the happiness with the Egyptian people. In this context, for the EU countries considering Israel's security in the region, European Union followed a more cautious policy in Egypt because of the emergence of popular movements in Egypt and the predominance of Islamic structures. Behr (2012) stated about the policy of EU after Arab Spring as;

... when it comes to the democratic transition processes in the region, the EU's new policy is unlikely to have a significant impact or to translate into a new role for the EU as a promoter of "sustainable stability" in the region. Similarly, the EU has so far failed to stake out a viable new position for itself in the emerging geopolitical context of the Middle East. What makes matters worse is that the EU's commitment to Arab democracy once again appears to be sidelined by its broader geopolitical goals. This makes it more and more unlikely that the EU will act as a driver for change in the southern Mediterranean. Instead it seems bound to pursue a new variation of its long-standing Euro-Mediterranean vision that places partnership over democratic principles (p.87).

In the history of the MB for the first time, elections in the Middle East have led to a worrisome situation in many issues in the EU. Western states have experienced the fear that they would lose their sovereignty over Egypt. This is because the Muslim Brotherhood's Islamic discourse and the foreign policy they pursued during their one-year rule are different from the politics of the Egyptian political leaders to which Western states are so accustomed. As a result, the US, Israel and the European Union were not satisfied with the policies of the MB. Unlike the Mubarak regime, the policies of the Morsi administration raised concerns that the EgyptianWestern alliance, which had existed for a long time, might be damaged as predicted. The EU had not provided strong support for reforms and power in Egypt during the transition period of democracy. The EU had perceived the Muslim Brotherhood Movement in general terms on the perception of the actors in domestic politics, media and soldiers. They did not provide the necessary support to Egypt during the transition period of democracy. In this case, the democratic transformation in Egypt made the process even more fragile which resulted in a military coup on the $3^{\text {rd }}$ July 2013. In July 2013, after Morsi was removed from office by the General Abdulfettah AlSisi, the European Union made a faint call for the release of President Morsi, who was arrested during the coup in Egypt. The EU Foreign Policy Unit Report (2014) stated about the situation in Egypt as "EU member states agree informally to suspend export licenses for some types of equipment that could be used for internal repression, but do not impose an arms embargo or other negative measures" (p.14). Just after the coup, as the Sisi administration imprisoned 528 anti-coup people in Egypt. The Foreign Minister of Germany, Frank-Walter Steinmeier (2014) explained that "it is not a positive trend in the European Union that the majority of the people in Egypt continued to be exempted from the political representation" (dw.com). In September 2014, following general elections, Sisi made formal negotiations in various EU countries. Therefore, Sisi's politic negotiations showed that European Union does not care about the democracy of the democratic election. After the coup on the $3^{\text {rd }}$ of July, the America and the Gulf states avoided calling the Egyptian coup as a military coup d'état. The European Union did not describe the military coup d'etat in Egypt as a 'coup'. Therefore, this showed that European Union had a similar attitude to the US with the statement he made in the EU. The former High Representative of the EU External Relations and Security Policy, Catherine Ashton explained that after taking control of the army in Egypt "I challenge all sides of Egypt to retail to the democratic process including free and fair presidential and parliamentary elections in the framework of the new constitution". The newly elected president had to govern in a completely inclusive approach so that the country could survive and complete the democratic transformation". A spokesman for the EU Commission said that while the process of going to the coup was assessed, "the army in Egypt has moved into action 
Turan, S. (2018). The role of external factors on the failed transition to democracy in Egypt. Journal of Human Sciences, 15(4), 2357-2375. doi:10.14687/jhs.v15i4.5598

with the support of a significant majority of the Egyptian people, because of the rising tension and polarization". These show that EU did not support Islamic governance as the members thought that Morsi's government could not respond to the expectations of the people and did not make necessary reforms in the country. Although these statements, contradicting the EU's democratic principles, show that the EU was, in fact, a dilemma between 'stability' and 'human rights' in the region. The Conversation (2013) emphasized the attitude of the EU "the EU has always preferred stability over democracy in the Middle East, conscious that any political change towards democratic reforms in this region would produce instability in the short to medium term" (theconversation.com). It is important that the degree to which new parties in power such as in Egypt, where democracy is beginning to take a turn for the better, attract importance to the relations with the West, and that it cannot protect the interests of the region after the transformation is complete. Concerns such as 'political Islam' show that the West prefers the 'stability' that has taken place for a long time.

After the army's coup in Egypt ousted Morsi, the first elected president of the country, the opponents gathered in Rabiat'ul Adeviyye Square to protest the coup and declared that they would not withdraw from the squares until Morsi returned. The international community, especially the EU and the US, have remained silent about the massacres committed by the army against the Muslim Brotherhood and the demonstrators. The international community and the EU have not provided the necessary support for the democratic transformation of Egypt. Having had significant roles in the democratic transformation of Eastern Europe, the EU did not have an effective role in the democratic transformation of Egypt. Barnes (2013) stated that "the impact of our democracy and governance activities in Egypt has been limited and unnoticeable in indexes describing the country democratic environment" (p.62). The silence of the EU and the international community gave 'legitimacy' to coup management. The crisis in Egypt has also adversely affected the expected change in the region with the Arab Spring. The crisis in Egypt, which has led Arab geography for many years with the possibility of lasting longer, continues to adversely affect Egypt and the region in the short term.

The EU, which strived to be constructive throughout the lives of Egypt, organized a meeting with the member foreign ministers in August of 2013, in response to the violent suppression by policy of the military administration to Morsi supporters. The EU decided that the embargo should be applied to all kinds of goods that may be used for violence at the meeting, and they decided to rethink financial aid in addition. Some members of the EU had not found enough of the democratic development level in Egypt as time goes on, and they were quite disturbed by social and sectarian disagreements. The European Parliament, which could not clearly show that it is anticoup, had demanded to stop the aid in March 2013. Yet, the EU had not stopped financial support for Sisi's military administration, as it would undermine the interests of corruption in Egypt. The EU had stopped the arms trade to Egypt in order to prevent its use only for the people. In order to influence the coup, the EU has used many instruments either individually or separately, including: economic and humanitarian aid, various sanctions, and military interventions that they did not like much during their history. However, the variety of tools the EU used in this process does not show that it has undergone a change at the core of the policy that it is trying to carry out in the region. Since the countries of the MENA region differ from each other in every sense and give different reactions to the same events, the EU has preferred, especially to support of political change in some regions while maintaining the existing authorities to help stability in some countries. Unless the EU's approach, which positions the EU upside down and centered on Europe, is changed, more and more various instruments will be the more it will not lead to a real change and development in relation to the regional countries.

It is seen that the EU is pursued softer and constructive policies in Middle East politics, not destructive like the US. The EU has the means to improve its economic and commercial relations and to ensure its own security, while taking into account its own interests, rather than changing the borders and locations of the countries or regimes in the region. It is also aimed to 
Turan, S.. (2018). The role of external factors on the failed transition to democracy in Egypt. Journal of Human Sciences, 15(4), 2357-2375. doi:10.14687/jhs.v15i4.5598

continue to meet energy needs by providing stability to the region. Of course, the recent financial crisis has prevented the EU from being an effective foreign policy. It is also far from reality to be able to provide sufficient financial support alone to the countries of the region. The EU is having a hard time to fully imagine its current policy towards Egypt due to the problems in the region as well as the incompatibilities it has experienced within itself. One of the most important reasons for this is the fact that they have different opinions and interests among the members of the Union, and that the EU wants stability instead of democratization in the region. In other words, the EU, which is experiencing a democratization-stabilization dilemma, preferred ensuring security in the shortterm regional countries while democratizing and stabilizing the countries in the long run. Of course, since it is not possible for the authoritarian regimes in the region to internalize and embrace the concept of democracy without a serious power pushing them, the EU is at the point of producing and executing foreign policy, transitioning from the idealistic preferences to the real worry in Egypt. The EU needed to rapidly change the policies and rhetoric against the coup in Egypt. The EU preferred to ensure its own security and stability in the region instead of turning the authoritarian regime in Egypt to democracy. Therefore, Islamic radical movements have strengthened, resulting in an increase in illegal immigration. There is a terrible sense that terrorist structures have begun to take effect in the world. In order to change this trend, there must be new mechanisms that will enable Egypt to enter the axis of democratization again, taking into account past experiences. The unstable situation of the region is a great threat not only to the EU but also to all the rest of the world. For this reason, it is also wrong to treat only the EU as responsible for resolving the chaos in the Middle East and push the EU on its own. Already experiencing serious problems, the EU must provide support to international organizations like the USA, Russia, China and India as well as the United Nations, the Organization for Security and Cooperation in Europe (OSCE) and the Arab League. In order to evaluate the EU's approach to the Arab Spring process, regarding the events that took place in the region, each member preferred to implement a policy in line with its own national interests while remaining inadequate and reluctant to form a common foreign policy. The MENA region has led to serious divisions among EU members, ranging from illegal immigration to the fight against terrorism. This diversity has become more evident with the beginning of the Arab Spring, and the division into military intervention in Libya has started to be felt seriously. On the other hand, it would not be wrong to say that the European Union is helping the countries in the MENA region in the transition period of democracy by using various economic, political and cultural means to protect their national and regional interests because they really want to see democracy in these countries. The EU mainly deals with economic aid in the region, the area and groups to which these benefits are transferred. Some financial programs, the use of various civil society instruments, have focused on short-term tools. The members link the relationship with the countries of the region to a short-term plan rather than a long term one. From here it is clear that neither the EU nor its members are far from being a strong global actor in the Middle East, preferring to prepare their plans for a maximum of five years, although it is necessary to plan for at least 25-30 years so as to become a global power. The European Union's plan for the region after a 30 -year period seems to be impossible to understand at this stage.

The Arab Spring process has resulted in a revolution in Egypt, but since economic development has not been achieved and external interventions have continued, instability has begun in the country. Although Morsi's domestic and foreign policy is ambitious, Morsi has been removed from the administration by powerful military coups because he could not offer solutions to internal confusion and economic problems in the country. Subsequently, Egypt entered a new process, and the power struggle between the pro-revolutionists and the coup supporters began. As a result, even if the developments in Egypt were related to the democratic transition, it was frustrating that the political and economic demands of the people of the country were not overcome after the Arab Spring. This has also shown that political transformation is not enough for such movements to be successful. Political needs must be complemented by economic and social needs. The EU has preferred to be more cautious in order to not repeat the mistakes it made in 
Turan, Ş. (2018). The role of external factors on the failed transition to democracy in Egypt. Journal of Human Sciences, 15(4), 2357-2375. doi:10.14687/ihs.v15i4.5598

Tunisia in the first place to the events in Egypt. Since Egypt is an important country in many respects for the EU, the EU has been in favor of keeping the relationship with Egypt in good condition in all circumstances while carrying out the policies accordingly. They had good relations that EU with Morsi, who succeeded Mubarak's withdrawal, also aimed to establish good relations with Sisi too who took the power by a military coup d'état. This policy of EU proved that the EU would do its utmost to ensure stability in Egypt, not for democracy.

\section{The Role of the Other Western Countries}

In the process military coup in Egypt, which caused regime changes in the country and failure to transition to democracy, the death of thousands of people, Germany did not take a prointerference stance in the first instance as opposed to other European countries. Germany has acted with a preference for economic sanctions instead. Germany's Egypt policy also provides some clues about the EU's Egypt policy. When the EU's Egypt policy was noticed, it was seen to be parallel to each other in general terms. The major reason for this is the fact the EU in the German control, which is not in the forefront as a political force in Egypt, is under German influence in this respect. Thus, the ineffective Germany in the Egypt and ineffective EU in the Egypt equation emerged. Germany had supported the opposition in the face of the events that started before the coup in Egypt. As a result, it is possible to see that Germany follows a line in support of financial assistance to all countries, mainly against harsh interventions, in view of Egypt policy. For this reason, it appears that Germany, which does not stand out as an effective force in the military coup in Egypt, has a policy of self-positioning, but not in a very effective position. The British administration, which did not show a primal attitude towards the military coup in the Egyptian counter-revolution and did not support the pro-democratic opponents, contributed to the regional and global legitimacy of the military regime. Following an equidistant politics with the USA at the time of the coup in Egypt, England communicated with the Sisi administration immediately after the coup and aimed to protect his economic and political interests in the new era. Martin (2013) stated that from the statements of William Hague;

Britain will work with the new regime in Egypt while not supporting military intervention. The Foreign Secretary said the overthrow of Mohamed Morsi was a 'dangerous thing' that risks setting a precedent in the volatile region. But he said the UK will be forced to work with the army-backed government to protect Britons and British firms in the country. It's of course a dangerous precedent to do that, if one president can be deposed by the military then of course, another one can be in the future - that's a dangerous thing. 'It's happened, so we have to recognize the situation will move on.' Deputy Prime Minister Nick Clegg said the Government did not support coups and wanted Egypt to a return to democratic rule as soon as possible. He added: 'We recognize states, not governments. We recognize the state of Egypt and we have to work with whoever is in authority in Egypt, we have to do that for the safety of British nationals. We have to do that because there are so many British companies there. There isn't really any question of not recognizing a particular government (dailymail.co.uk).

Similarly, the former British Foreign Secretary David Miliband criticized the British and Western governments' silence against the coup in Egypt, emphasizing the intervention against democracy as a coup and supporting non-extremist Islamic movements in countries like Egypt. Mr. Miliband said: "I think we've got to be clear this was a coup." He added that "the entry of Islamist parties - so-called 'political Islam' - into the democratic process is a good thing, not a bad thing, that political prisoners need to be released, and genuinely democratic politics restarted in Egypt" (ft.com). The fact that the administration of Abdulfettah Al-Sisi, who encouraged the unresponsive attitude of the Western countries to the coup, carried out massacres in the squares of Rabia and Nahda on the $14^{\text {th }}$ of August did not change the attitude of the United Kingdom. Foreign Minister Hague said he was "saddened by the violence in Egypt and that the killing of the protesters was unacceptable. Having no criticism of the military coup d'état and not commenting 
on the killing of thousands of people, Hague made it clear that they should support democratic institutions and political dialogue in Egypt. The fact that Britain did not criticize the activities of the coup administration in Egypt is an indication that Britain has taken a position against the Muslim Brotherhood in the process of counter-revolution, although it did not directly support the coup. The most important reason why Britain did not react to the civil liberty abuses and antidemocratic implementations of the Egyptian Sisi administration was the economic relations of London with Cairo. In order to keep these relations alive, Britain has not reduced its interaction with the Sisi administration. Britain has $50 \%$ of all foreign investments in Egypt. The economic and trade agreements, which are among the biggest foreign investments in Egypt's history, also revealed the motivation of Britain's politics in Egypt's counter-revolutionary period, which did not react to the human rights violations of the Egyptian military administration in the interest of protecting economic interests.

To summarize the politics of the British counter-revolutionary period in Egypt, it must be said that economic and political interests outweigh democratic values. London, which did not want its investments in Egypt to be dangerous, demanded the continuation of the new status quo that by not reacting to the civil liberty abuses that followed the coup d'état under the leadership of Abdal Fatteh El-Sisi. The UK and its global and regional partners, the US and Israel, followed the same policy, facilitating London's work in this process and causing future reactions to remain at a lower level due to this policy.

\section{Conclusion}

The global actors have always made plans for their interests in the world. They use different methods to reach their goals. They can develop detailed roadmap to the target region. The MENA region especially Egypt is one of the targeted region for the global actors. Global actors were not in favor of the establishment of democracy in Egypt as their own interests might not be met by the democratically elected president. Actually, they faintly condemned the dismissal of Morsi, by force of military coup, who had come to power with a democratic election. Beside this, they also stated that they would be able to do the task for the Al-sisi administration. To sum up, "the European Union has not produced serious policies on democratization. There is no effect of Western aid on democracy" (Desai 2012:2). There are two reasons for this. First, although the European Union has stated that it gives priority to issues such as democracy, human rights and the rule of law, it has in fact given priority to issues such as the development of migration, trade and economic relations. Therefore, topics like democracy and human rights are lower on the agenda for the European Union. On the other hand, there is no perfect harmony between the members of the Union on foreign policy production. Disagreements among the Member States prevent the European Union from producing a concrete and clear policy. Egypt is important for geostrategic and geopolitical aspects for the Western countries, especially the EU. The Israeli-Palestinian problem, radical Islam, the fight against terrorism and intense cooperation on trade and energy are the reasons for this great importance. For these reasons, the EU has always been in favor of good relations with the Egyptian authorities. The EU has progressed in the same way as Egypt on the peace settlement in the Middle East while developing Egypt's cooperation in areas such as security, migration, weapons of mass destruction and terror after 9/11. There have been disputes between the EU and Egypt for some time in the field of human rights, but the EU's misrepresentation of human rights abuses in Egypt has hurt the image of the EU. While the EU was criticizing Mubarak for violating human rights in Egypt, violations were limited to liberal movements and individuals only. For example, while the EU on one side reacted very seriously to the arrest of Eymen Nur and liberal intellectual Saadettin Ibrahim, who are among the liberal dissidents of Egypt, they kept silent about the arrested members of the MB. The USA was also in the same line with EU owing to their interests and security issues. 
Turan, S.. (2018). The role of external factors on the failed transition to democracy in Egypt. Journal of Human Sciences, 15(4), 2357-2375. doi:10.14687/jhs.v15i4.5598

\section{References}

Abbasi, A. M. (2012). The Arab world: democratization and Islamization? International Journal on World Peace. 29(1), 7-19.

Archick, K., Belkin, P., Blanchard, C. M., Ek, Carl., \& Mix, Derek E. (2011). Muslims in Europe: Promoting Integration and Countering Extremism report, Washington D.C.

Barnes, A. (2013). Creating Democrats? Testing the Arab Spring. Middle East Policy, 2013, vol. XX, no. 2, pp. 55-72.

Behr, T. (2012). The European Union's Mediterranean Policies after the Arab Spring: Can the Leopard Change its Spots? Amsterdam Law Forum Vol 4:2, pp. 77-88.

Bingöl, Y. (2007). “Kırgızistan'ın 'Renkli’ Devrimi: Demokrasiye Geçiş mi, Küresel Rekabet mi?” Kocaeli Üniversitesi Sosyal Bilimler Enstitüsü Dergisi, no. 13, 1-21.

Brussels A 70/13 Press. (2013). "EU's response to the "Arab Spring": The State-of-Play after Two Years.

Ceyhun, O. (2013). AB’nin Kopenhag Kriterleri Müslümanlar için değilmiş! retrieved May 05, 2015 from http://www.hurhaber.com/ozan-ceyhun/ab-nin-kopenhag-kriterleri-muslumanlar-icindegilmis/yazi-15401

Dersan, D. (2006). Dynamics and Evolution of European Union's Middle East Policy, Unpublished Doctoral Dissertation, Middle East Technical University, Turkey.

Desai, R. (2012). The Challenge of a Reform Endowment. Washington: Brookings Institute.

DW News. (2013). "Fresh clashes in Egypt as US envoy William Burns continues talks" retrieved September 15, 2015 from http://www.dw.com/en/fresh-clashes-in-egypt-as-us-envoy-william-burnscontinues-talks/a-16952574

European Commission. (2011). A Partnership for Democracy and Shared Prosperity With the Southern Mediterranean, Joint Communication to the European Council, the European Parliament, The Council, The European Economic and Social Committee and the Committee of the Regions, Brussels, retrieved April $\quad 04, \quad 2014$ from https://ec.europa.eu/research/iscp/pdf/policy/com_2011_200_en.pdf

Farouk, Y. (2014). More than Money: Post-Mubarak Egypt, Saudi Arabia, and the Gulf. GRC Gulf Paper. Pp.1-24.

Fortna V. P. \& Huang, R. (2012). Democratization after the civil war: a brush-clearing exercise. International Studies Quarterly. 56, 801-808.

Hamid, S. (2011). The struggle for Middle East democracy: Why the Arab Street finally revolted. Cairo Review, no. 1, pp. 18-29.

Mahalli, H. (2011). Hangi Demokrasi Retrieved March 12,2017 from https://www.aymavisi.org/guncel/Hangi $\% 20$ Demokrasi $\% 20-\% 20 \mathrm{Husnu} \% 20 \mathrm{Mahalli.html}$

Martin, D. (2013). We'll work with regime, says Hague: Foreign Secretary says Britain does not support Egypt's military intervention and coup was 'dangerous thing'. Retrieved May 30, 2014 from http://www.dailymail.co.uk/news/article-2356534/William-Hague-says-Britain-does-supportEgypts-military-intervention-coup-dangerous-thing.html

Murphy, D. (2014). "When it comes to Egypt, take note of American actions, not words", Christian Science Monitor.

Oğuzlu, T. (2011). “Arab Baharı Yansımaları”, ORSAM. Cilt:3, Say1: 36. pp. 8-16.

Prashad, V. (2012). Arab Spring: Libyan Winter Oakland: Ak Press, See the Turkish translation of this book; Vijay Prashad, Arab Baharı: Libya Kışı, trans. Şükrü Alpagut 2012 Istanbul: Yordam Yayınları.

Perthes, V. (2011). Europe and the Arab Spring, Stiftung Wissenschaft und Politik, Vol. 53 no. 6 pp. $73-$ 84 DOI 10.1080/00396338.2011.636273

Snider, E. \& Faris, D. (2011). “The Arab Spring: U.S. Democracy Promotion in Egypt”, Middle East Policy, Vol: 18, No: 3, pp. 49-63.

The Conversation. (2013). Mixed messages from the EU won't help solve Egypt's crisis, Retrieved May 29, 201 from http://theconversation.com/mixed-messages-from-the-eu-wont-help-solve-egyptscrisis-16595

Usembassy. (2015). "Secretary Kerry at the U.S.-Egypt Strategic Dialogue” Retrieved September 23, 2016 from https://eg.usembassy.gov/secretary-kerry-u-s-egypt-strategic-dialogue/

Yazıc1, H. (2014). Turkey as A Role Model for The Arab Awakening in the Middle East, P.h.D Thesis Submitted to Yeditepe University, İstanbul. 